\title{
Analysis of the Performance of Employees with the Methods of Human Resources Scorecard and Analytical Hierarchy Process in the Labor Outsourcing Company
}

\author{
Kharisma Islamy ${ }^{1}$, Erry Rimawan ${ }^{2}$, Farih Hidayat ${ }^{3}$, Farid Faraitody ${ }^{4}$ \\ Department of Industrial Engineering ${ }^{1,2}$, Department of Magister Management ${ }^{3,4}$ \\ Mercu Buana University, Jakarta, Indonesia
}

\begin{abstract}
Corporate services are service providers. A good service company should give the best possible service in order to create its own satisfaction for customers. Therefore, there is a greet need for qualified human resources. A company's success is based on it's performance, if an employee's performance is bad then it produces a bad company. This is where human resources are concerned. With the methods of Human Resources Scorecard and Analytical Hierarchy Process this can help to see if the company's employee's performance is good or not. On the method of Human Resources Scorecard are the four perspectives of financial perspectives, customer perspectives, internal business process perspectives, and learning \& growth perspectives. The four perspectives have the strategy of objectivity, from the strategy of objectivity, the key performance indicator. Research result from the use of both method of human resources scorecard and analytical hierarchy process, show that the employee performance assessments in this company have increased from a 4,03 score which can mean good employee performance to 4,51 which can mean very good employee performance.
\end{abstract}

Keywords:- Employee Performance, Human Resources Scorecard, Analytical Hierarchy Process.

\section{INTRODUCTION}

The role of employees is very important to the company. Each company is required to raise its performance in the face of competence. That's why it's important to perform an employee performance evaluation on the company. To see whether the company has optimal performance attainment. Companies need to measure their performance comprehensive so that they can know what factors have not been reached to shape better employee quality performance. Moreover, shaping these companies with a focus on outsource resource providers is expected that they will also be able to help improve the quality of the work given to them by outsource employees.

The company is present among business people in the country to join hands with all stakeholders in finding solutions to optimize the management of business processes and the availability of labour support. The competent professional to maintain adaptability to changes while supporting the business objectives of the customer company is more sustainable.

It is hoped that in the next five years, the company will be able to show continued growth with the application of new technologies and comprehensive services in employment to its cusctomers. Each company has its own strategy map to achieving the corporate vision. Here is the company's strategy map:

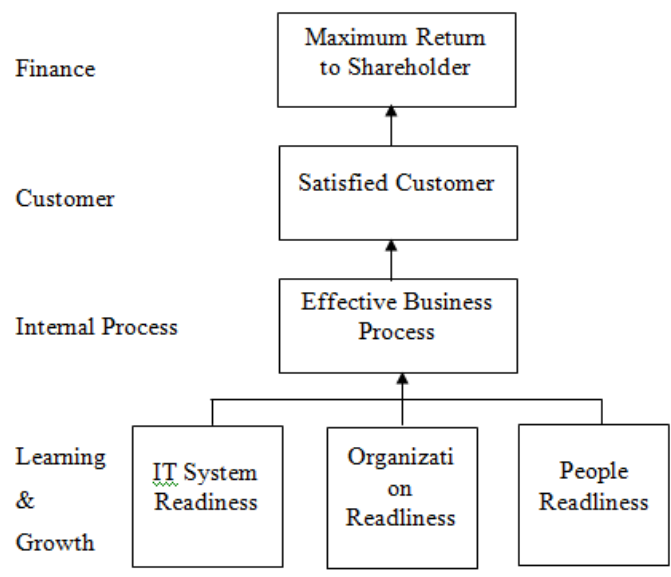

Fig 1

Source: Company data, 2019 
To achieve the corporate vision, it requires a strategy map like the diagram above. Each perspectives has its own strategy, from financial to learning $\&$ growth.

\section{REVIEW OF LITERATURE STUDY}

\section{$>$ Performance}

Performance is the extent of one's success in carrying out a task to accomplish a set global. The factor that influences performance is the ability and motivation factors. The purpose of the measuring of employee performance is as follows:

Knowing the extent of the organiztions's expansion of purpose

- Provide staff learning tool

- Improve performance next period

- Gives systematic consideration to decision-making

- Motivate the staff

- Creates public accountability

\section{> Human Resources Scorecard}

Human Resources Scorecard is a comprehensive system of measuring human resource performance by describing company vision, mission and strategy. The difference between human resources scorecard with balanced scorecard is that balanced scorecard measures a company's performance of proportionate assets while human resources scorecard weighs more than the human resources performance with artificial assets. The following are steps in measuring human resources scorecard:

- Define the company's strategy clearly

- Creating a company strategy map

- Identify HR Deliverable on the strategy map

- Designing a system for measruring strategy

- Managing implementation through measurement

$>$ Human Resources Scorecard as a Model of Measuring Human's Performance

Human resources scorecard measures the effectiveness and efficiency of human data sources in mobilizing employee behavior to achieve company strategy goals and thus can help demonstrate how human resources contribute to financial successs and company strategies. According to the beker al (2001) the basis for strategic human resources roles consists of a three-dimensional value chain developed by the corporate human resources architecture, which is the function, systems and behavior of the work. The architecture of human resources can be seen in the accompanying picture:

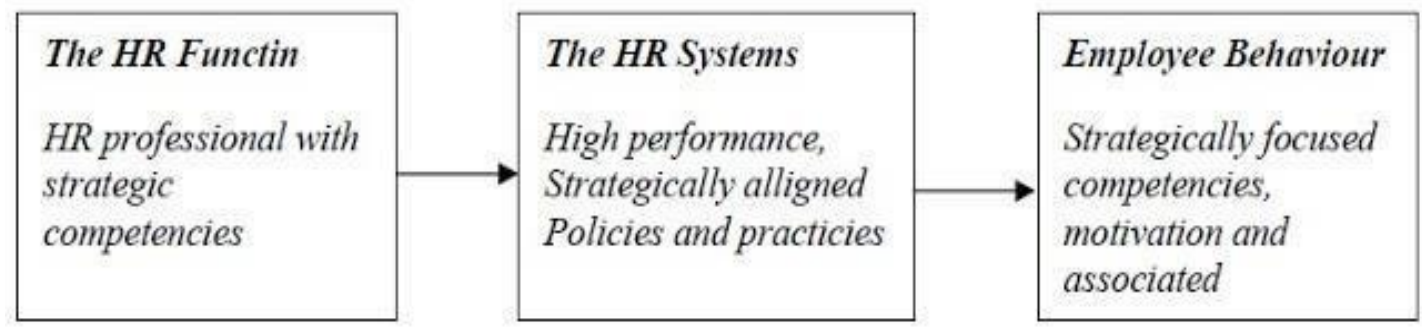

Fig 2:- Human Resources Architecture

\section{$>$ Analytical Hierarchy Process}

Analytical hierarchy process is an ideal method that can provide an alternative level or level description when some criteria and sub-criteria in the dicision making process. Measures in the use of the analytical hierarchy process method by saaty (1988) as follows:

- Define the problem and elaborate the desired solution

- Load the corresponding matrix needed to develop the matrix device

- Synthesize the data in a matrix pair

- Testing consistency and priorities that have been acquired

- Take the top steps for each level

- Using hierarchical compositons

- Using hierarchical composition to cover priority vectors with criteria weight
- Evaluating consistency for the whole hierarchy by quantifying each consistency index with the priority of the corresponding criteria

\section{METHODOLOGY}

The purpose of this research is to measure the performance of human resources and human resources if the workman is already optimal or not yet. This research is a descriptive research using the Human Resources Scorecard method and Analytical Hierarchy Process (AHP) method. Descriptive research is research that aims to explain problem solving based on facts in the field by presenting data, analyzing, and interpreting. This research is a quantitative research. In this study using two types of data, namely primary data and secondary data. 


\section{RESULT}

Below is perspective data in the company based on negotiations between company leaders and researchers with the objectivity strategy and key performance indicators:

\begin{tabular}{|c|c|c|}
\hline Perspective & Objective Strategy & Key Performance Indicator \\
\hline \multirow{4}{*}{ Customer } & Increased Employee Productivity & Creating a Comfortable Work Environment \\
\hline & Increased Employee Welfare & Providing Guarantees to Employees \\
\hline & Maximizing the Use of Company Assets & Using Company Assets as Needed \\
\hline & Investment Strategy Optimization & Understanding Risk Tolerance \\
\hline \multirow{4}{*}{ Customer } & Increased Employee Satisfaction with Work & Provide the best service \\
\hline & Improving Service Quality for Customers & Listen to customer complaints \\
\hline & Increased Customer Loyalty & Prioritize Service to Customers \\
\hline & Increased Customer Needs & Complete All Customer Needs \\
\hline \multirow{4}{*}{$\begin{array}{c}\text { Internal Business } \\
\text { Process }\end{array}$} & Improved Communication Between Employees & Doing Team Work in rotation \\
\hline & Improved Product Quality Provided & Reviewing Customers \\
\hline & Superior Leadership & Creating Good Communication To Employees \\
\hline & Improved Occupational Safety and Health & Conducting a Regular Work Environment Check \\
\hline \multirow{4}{*}{$\begin{array}{l}\text { Learning \& } \\
\text { Growth }\end{array}$} & Increased Hard Skill of Employees & Tightening When Accepting New Employees \\
\hline & Increased Soft Skill of Employees & Conduct Training for New Employees \\
\hline & Improved Employee Evaluation & Conducting Employee Ratings \\
\hline & Improvement of Recruitment Standards & Make Employee Criteria Standards \\
\hline
\end{tabular}

Table 1:- Objective Strategies and Key Performance Indicators

\begin{tabular}{|c|c|c|c|c|c|c|}
\hline Criteria & Financial & Customer & Internal Business & Learning \& growth & Total & Priority Vector \\
\hline Financial & 0.23 & 0.16 & 0.38 & 0.25 & 1.02 & 0.26 \\
\hline Customer & 0.57 & 0.39 & 0.20 & 0.55 & 1.71 & 0.43 \\
\hline Internal Business Process & 0.10 & 0.39 & 0.20 & 0.10 & 0.79 & 0.20 \\
\hline Learning \& Growth & 0.09 & 0.07 & 0.21 & 0.10 & 0.48 \\
\hline \multicolumn{7}{|c|}{ Total } \\
\hline
\end{tabular}

Table 2:- Normalizing the Criteria Tab

After getting the weight of each perspective, the next step is to calculate the value of the consistency ratio. As a reference of the ratio value, a data can be said to be consistent if it has a value smaller than $10 \%$ or 0.1 . After obtaining a consistency ratio for all consistency criteria and sub-criteria further testing consistency for the entire hierarchy with the formula:

$$
\begin{gathered}
C I=\frac{\lambda \text { maks }-n}{n-1} \\
C R=\frac{C I}{R I}
\end{gathered}
$$

$\mathrm{CR}=$ Consistency Ratio

$\mathrm{RI}=$ Random Index

$\mathrm{N}=$ Order Amount 
ISSN No:-2456-2165

\begin{tabular}{|c|c|c|c|c|c|}
\hline Criteria & Financial & Customer & Intemal Business & Leaming \& Growth & Priority Vector \\
\hline Financial & 0.23 & 0.16 & 0.38 & 0.25 & 0.26 \\
\hline Customer & 0.57 & 0.39 & 0.20 & 0.55 & 0.43 \\
\hline Internal Business & 0.10 & 0.39 & 0.20 & 0.10 & 0.20 \\
\hline Leaming \& Growth & 0.09 & 0.07 & 0.21 & 0.10 & 0.12 \\
\hline Total & 1.00 & 1.00 & 1.00 & 1.00 & 4.00 \\
\hline \multicolumn{7}{|c|}{$\lambda \mathrm{Max}$} \\
\hline CI & 0.33 \\
\hline RI & 0.09 \\
\hline CR & $1.22=1 \%$ \\
\hline
\end{tabular}

Table 3:- Ratio Comparison Recapitulation

The following is a recapitulation of the values of the consistency ratio of each perspective:

After scoring key performance indicator, the next step is weighting each key performance index with a key performance indicator score. After calculating the weighted scores in each key performance indicator perspective, the next step is to measure the performance of employees in each perspective with a weighted score. Here is the measurement table:

\begin{tabular}{|c|c|c|c|c|c|c|}
\hline \multirow{2}{*}{ KPI perspective } & \multicolumn{3}{|c|}{ March - Augst 2019 } & \multicolumn{3}{c|}{ Septemper 2019 - February 2020 } \\
\cline { 2 - 7 } & Wieght & Score & Weighted Score & Weight & Score & Weighted Score \\
\hline Perspective Financial & 0.26 & 3.85 & 1.00 & 0.26 & 4.47 & 1.16 \\
\hline Perspective Customer & 0.43 & 4.18 & 1.80 & 0.43 & 4.55 & 1.96 \\
\hline Perspective Internal Business & 0.20 & 3.65 & 0.73 & 0.20 & 4.07 & 0.81 \\
\hline Perspective Learning \& Growth & 0.12 & 4.22 & 0.51 & 0.12 & 4.80 & 0.58 \\
\hline \multicolumn{2}{c}{ Total } & & 4.03 & & & 4.51 \\
\hline
\end{tabular}

Table 4:- Measurement of each perspective with a weighted score

After finding the weighted results in each perspective, it then determines employee performance appraisal to find out whether it is good or not. Following is the performance evaluation:

- Weight 1.0 - $1.8=$ Very poor employee performance

- Weight 1.8 - 2.6 = Poor employee performance

- Weight 2.6 - $3.4=$ Moderate employee performance

- Weights 3,4 - 4,2 = Good employee performance

- Weight 4.2 - 5.0 = Very good employee performance

Based on the weight of the employee performance appraisal above from the perspective of the human resources scorecard, it can be concluded that in March to August 2019 a weighted score of 4.03 can be interpreted as good employee performance, while in the septermber 2019 to February 2020 get a weighted score of 4.51 which can be interpreted as very good employee performance. Thus, this company has a very good performance due to the absence of significant changes.

\section{CONCLUSIONS}

Measurement of employee performance with the scorecard human resource method and analytic hierarchy process method produces a financial perspective, customer perspective, internal business process perspective, and learning \& growth perspective in March 20219 - August 2019 with a total score of 4.03 which can be interpreted as performance very kind employees. While in September
2019 - February 2020 had a total score of 4.51 which can be interpreted as very good employee performance. Increase the ability to improve performance of outsourcing companies to improve performance.

\section{REFERENCES}

[1]. Anwar, S. 2011. Supply Chain Management: Concepts and Nature. Journal of Information Technology Dynamics, 3 (2)

[2]. Becker Brian E, Hunselik Mark A, Ulrich Dave. 2001. "The HR Scorecard : Lingking People, Strategy, and Performance", Harvard School Press.

[3]. Christoper \& Scooner. 2007. Incrementalism: Eroding the Impediments to a Global Public Procurement Market. Journal of International Law. Page 529

[4]. Hayati, E.N. 2014.Supply Chain Management (SCM) and Logistics Management. Technical Dynamics, Vol 8 (1). Pages 25-34

[5]. Kadarshah, S., and Ramdhani, A. 2000. Decision Support Systems A Structural Discourse Idealization and Implementation of Decision Development Concepts, 2nd ed., Wuly Anisah, Ed. Bandung, Indonesia: PT. Teenage Workshop

[6]. Kaplan, Robert S, and Norton, David P. 2000. "Balanced Scorecard : Implement strategy into action", Jakarta: Erlangga Publisher. 
[7]. Pujawan, I.N., and Mahendrawathi. 2010. Supply Management. Surabaya: For Widya

[8]. Rainnita 2013. Evaluation of Suppliers of Cement, Bricks and Sand Using Analitycal Hierarchy Process Method in CV. Bagiyat Mitra Perkasa. ST. Soegijapranata Catholic University of Semarang.

[9]. Saaty, T.L. 1990. How To Make a Decision: The Analytic Hierarchy Process. European Journal of Operational Research 48, Vol. 48.

[10]. Saaty, T.L. 1994. Fundamentals of Decision Making and Priority Theory With The Analytic Hierarchy Process. RWS Publication: Pittsburgh.

[11]. Supardi, E. 2016. Export Import Theory and Practicum of Import Export Activities for Logistics and Business Practitioners (1). Yogyakarta: Deepublish 